\title{
Peran Program Pemberdayaan Kesejahteraan Keluarga dalam Pemberdayaan Perempuan di Kecamatan Telaga
}

\author{
${ }^{\mathbf{1}}$ Nikma Wahyuni Hanis, ${ }^{2}$ Atika marzaman \\ ${ }^{12}$ Program Studi Ilmu Pemerintahan, Universitas Gorontalo \\ Gorntalo, Indonesia \\ Email : ${ }^{1}$ nikmawahyuni96ug@gmail.com, ${ }^{2}$ tika.marzaman@gmail.com
}

Received: 13 November 2019; Revised: 13 Februari 2020; Accepted: 17 Februari 2020

\begin{abstract}
This study aims to determine the extent of the role of the family welfare empowerment program (PKK) in increasing women's empowerment in Telaga District. This research is a qualitative research with data collection method through interviews and documentation. The research results obtained that the implementation of the PKK program has provided many benefits in empowering women, especially in the village. The success was obtained thanks to government support at the sub-district level and also for direct coaching by the Gorontalo Regency PKK management to sub-district and village PKK. The PKK program is also not fully implemented. The main obstacles faced are the low capacity of the community, especially women, and the lack of mastery of technology. For this reason, active participation and full support from the government are needed in the development and maximization of the PKK program.
\end{abstract}

Keywords: Empowering; Family Welfare; Women

\begin{abstract}
Abstrak
Penelitian ini bertujuan mengetahui sejauhmana peran program pemberdayaan kesejahteraan keluarga (PKK) dalam meningkatkan pemberdayaan perempuan di Kecamatan Telaga. Penelitian ini merupakan penelitian kualitatif dengan metode pengumpulan data melalui wawancara dan dokumentasi. Hasil penelitian yang diperoleh bahwa pelaksanaan program PKK telah banyak memberikan manfaat dalam pemberdayaan perempuan khususnya di Desa. Keberhasilan diperoleh berkat adanya dukungan pemerintah di tingkat kecamatan dan juga atas pembinaan langsung oleh pengurus PKK Kabupaten Gorontalo kepada PKK kecamatan hingga desa. Program PKK juga belum sepenuhnya dilaksanakan secara maksimal. Hambatan utama yang dihadapi adalah masih rendahnya kapasitas masyarakat khususnya perempuan serta masih minimnya penguasaan terhadap teknologi. Untuk itu diperlukan partisipasi aktif dan dukungan penuh dari pemerintah dalam pengembangan dan maksimalisasi program PKK.
\end{abstract}

Keyword : Pemberdayaan: Kesejahteraan Keluarga; Perempuan

Link DOI : http://dx.doi.org/10.31314/pjia.8.2.123-135.2019 


\section{PENDAHULUAN}

Keputusan yang dikeluarkan oleh Pemerintah didalam merevitalisasi dan mengelompokkan Organisasi perempuan ini di bawah Departemen dalam federasi menyebabkan lahirnya Pemberdayaan dan Kesejahteraan Keluarga (selanjutnya disebut PKK), yaitu Organisasi yang mewadahi perempuan yang tidak berada di bawah Departemen. pada organisasi ini pada awalnya dari Pendidikan Kesejahteraan Keluarga yang didalamnya melibatkan partisipasi perempuan dan merupakan program pendidikan perempuan. sejalan dengan organisasi ini selanjutnya berubah menjadi pembinaan kesejahteraan keluarga yang berupaya tidak hanya saja mendidik kaum perempuan, akan tetapi membina serta membangun keluarga di bidang mental spiritual dan fisik material serta peningkatan sandang, papan kesehatan, serta mutu dan juga keluarga sejahtera.

Pergerakan perempuan merupakan bentuk pergerakan yang tujuannya sangat istimewa demi untuk menaikkan derajat (kedudukan) para kaum perempuan dalam masyarakat. keputusan dalam organisasi pergerakan emansipasi yang bertujuan untuk mencapai persamaan derajat antara wanita dan laki-laki yang tidak hanya sebagai jagonya memasak didalam rumah tangga saja, akan tetapi juga sebagai guru anak-anak. PKK merupakan gerakan Nasional yang tumbuh dari, oleh dan untuk masyarakat. dengan perempuan sebagai motor penggerak utama dalam mewujudkan keluarga yang bahagia, sejahtera, serta mandiri. peningkatan kualitas perempuan ini juga melalui program mengembangkan dan memanfaatkan berbagai potensi yang ada pada diri perempuan (Moedjanto, 2000).

Dari sisi programnya, organisasi PKK awalnya diarahkan untuk mendorong kemajuan parakaum perempuan agar bisa memainkan peran gandanya secara baik, yakni sebagai pengelola keuangan dalam keluarga serta bisa membantu mencarinafkah dan juga sebagai pelaku pembangunan. Akan tetapi sesuai dengan perkembangannya, pemberdayaan perempuan berkembang juga dalam kehidupan berkeluarga, bermasyarakat, berbangsa dan bernegara. Pemberdayaan perempuan merupakan suatu upaya untuk meningkatkan kemampuan peran supaya dapat melaksanakan fungsi dan peran dari pada perempuan itu sendiri. Selain itu, PKK diharapkan mampu membebaskan perempuan dari budaya patriarkhi, sehingga perempuan-perempuan memiliki jiwa kemandirian melalui PKK diharapkan harkat dan martabat perempuan sebagai bagian keluarga yang dapat ditingkatkan. namun, pada kenyataanya PKK belum sepenuhnya mampu merubah kondisi keluarga dan perempuan, sehingga belum terwujudnya kesetaraan dan keadilan Gender. Pemerintah melalui lembagalembaganya diharapkan memberikan ruang/peluang bagi kaum perempuan minimal $30 \%$ dalam berkreasi dan berinovasi agar peran perempuan dalam pemerintahan dapat lebih dimaksimalkan (Pontoh, 2013). Dengan begitu, merujuk pada hasil penelitian PBB yang menyatakan bahwa jumlah minimum keterlibatan perempuan dalam politik memungkinkan terjadinya suatu perubahan dan membawa dampak pada kualitas keputusan yang diambil dalam lembaga publik (Iqbal, 2019).

Bergulirnya Reformasi dan disahkannya GBHN 1999 oleh MPR serta adanya paradigma baru pembangunan dan semangat Otonomi Daerah. maka kepanjangan PKK ini berubah menjadi Pemberdayaan dan Kesejahteraan Keluarga. dimana sebuah organisasi yang 
melibatkan yang melibatkan kaum perempuan dan keluarga dalam upaya mewujudkan keluarga yang sejahtera karena kesejahteraan keluarga menjadi tujuan utama dari organisasi PKK. Hal ini dikarenakan Keluarga merupakan unit terkecil masyarakat yang berpengaruh besar terhadap kinerja pembangunan. dari keluarga yang sejahtera ini, maka kehidupan berbangsa dan bernegara akan lahir ketentraman kedamaian, serta keharmonisan dan kesejahteraan menjadi salah satu tolak ukur dalam pembangunan.

Peraturan dalam negeri Republik Indonesia kementrian Nomor 1 tahun 2013 tentang pemberdayaan masyarakat dalam gerakan pemberdayaan kesejahteran keluarga Bab 1 pasal 1 ayat 5 berbunyi : "gerakan pemberdayaan kesejahteraan keluarga yang kemudian disingkat gerakan PKK yakni gerakan nasional yang pembangunan masyarakat dimulai dari bawah yang dimulai dari, oleh dan untuk rakyat demi terwujudnya kelarga yang beriman, dan bertaqwa kepada Tuhan yang maha Esa berbudi luhur, sehat, sejahtera dan maju serta mandiri.kesadaran akan kesetaraan gender, kesadaran hukum dan lingkungan". ini berarti bahwa organisasi PKK memiliki tugas untuk melakukan pemberdayaan terhadap masyarakat yang terutama pada perempuan.

Ruang lingkup kewenangan Tim Penggerak Pemberdayaan dan Kesejahteraan Keluarga (selanjutnya di singkat TP-PKK) bisa di bilang cukup luas seperti yang sudah tertuang dalam pasal 3 Peraturan Menteri Dalam Negeri Republik Indonesia Nomor 1 Tahun 2013 yakni sasaran pemberdayaan Masyarakat melalui gerakan organisasi PKK adalah keluarga diperdesaan yang kemudian perlu ditingkatkan dan dikembangkan kemampuan dalam mental, spritual, fisik dan material.
Organisasi PKK ini tentunya menjadi salah satu organisasi gerakan dalammendukung dan membantu programprogram Pemerintah dengan mendata beberapa segala aspek yang sangat diperlukan seperti data warga, data ibu hamil, bayi, balita, kelahiran, kematian sampai pada kegiatan masyarakat. PKK juga selalu memberikan pemahaman tentang agama yang kurang tepat, tentang pelarangan dalam penggunaan alat kontrasepsi termasuk mereka harus memberikan penjelasan yang jelas ktentang manfaat dari program KB kepada masyarakat yang rata-rata memiliki pendidikan rendah,dan juga membantu korban kekerasan perempuan dan anak dalam rumah tangga pada masyarakat. PKK juga berkonsen dalam membela kaum miskin yang kelaparan dengan cara memberikan bantuan ekonomi pada kaum perempuan.

\begin{tabular}{lccr}
\multicolumn{1}{c}{ Semua } & Program & PKK & banyak \\
berorientasi pada & aksi & nyata \\
memberdayakan dan memihak & kaum \\
perempuan. kontribusi para & kaum \\
perempuan dalam mensejahterakan
\end{tabular}
kehidupan keluarga sangta besar. selain menjadi pengelola dalam urusan rumah tangga, perempuan juga dituntut untuk membantu dalam mencari nafkah demi mencukupi kehidupan sehari-hari. selain itu juga, perempuan juga berperan sebagai pelaku pembangunan. Perempuan sebagai sumber daya manusia dalam pembangunan yang memiliki peran penting untuk membangun bangsa dan negara karena perempuan adalah motor penggerak dari pembangunan itu sendiri. Dengan demikian perlu diadakan pembinaan terhadap perempuan agar mereka mampu mejalankan peran gandanya dengan baik.

Kinerja TP-PKK Kecamatan Telaga sejauh ini sudah menunjukkan kinerja yang baik, ini dibuktikan dengan sudah dilakukannya beberapa kegiatan yang Copyright (c) 2019, Publik (Jurnal Ilmu Administrasi), ISSN: 2301-573X (Print), ISSN: 2581-2084 (Online) 
semuanya berkaitan dalam

memberdayakan masyarakat. yakni pada kesejahteraan keluarga dan dalam pemberdayaan masyarakat. seperti halnya, pada kegiatan pemanfaatan halaman pekarangan rumah untuk ditanami berbagai macam jenis tanaman rempah-rempah (dapur hidup) dan obat-obatan (toga) serta membentuk kelompok ekonomi produktif. Namun, perjalanan organisasi PKK di Kecamatan Telaga masih ditemui kendala dalam pelaksanaan program PKK. Kendalanya adalah : kurangnya sumber daya manusia, kurangnya pemahaman masyarakat atau kurangnya keingintahuan masyarakat terhadap program yang diprogramkan oleh PKK. Berbagai kendala tersebut menyebabkan masih tingginya persentasi angka kemiskinan di Kabupaten Gorontalo pada angka 19,27\% (Kabupaten Gorontalo, 2018). Persentasi ini menunjukkan bahwa masih rendahnya peran Organisasi PKK di Kecamatan Telaga.

Makna sederhana bahwa organisasi PKK dalam posisinya adalah bagaikan perangkat magnet yang dilengkapi dengan dua sisi yang berbeda dan juga berlawanan. disatu sisi, PKK mengusung format dan visi mulia untuk upaya pembebasan perempuan dalam wujud pemberdayaan. Organisasi PKK dapat dilihat pada beberapa hasil penelitian terdahulu bahwa organisasi PKK mampu memberikan motivasi sekaligus memberikan pelatihan kewirausahaan kepada kaum perempuan agar bisa menjadi individu yang mandiri dan berkualitas. namun, dilain pihak sejumlah kecenderungan kegiatan dalam PKK khususnya di kegiatan PKK Kecamatan Telaga justru banyak di maknai atau dilakukan hanya sebagai kegiatan rutin semata yang dipandang formalitas saja sehingga hal ini sangat diprihatinkan juga turut mempertanyakan bagaimana sebenarnya bentuk implementasi dari pada pemberdayaan perempuan serta keberadaan pemberdayaan dalam masyarakat.

Sebagaimana yang telah diuraikan diatas bahwa organisasi PKK ini memiliki peran penting dalam Pemerintahan,jika kemudian permasalahan yang dialami oleh pengurus PKK tidak diseriusi, maka tentunya ini akan berdampak pada pembangunan Desa, Kecamatan, Kabupaten atau bahkan sampai Provinsi dan sampai pada tingkat Nasional, karena mengingat keberadaan Organisasi PKK ini memegang peranan penting dalam Pemerintahan. Ini kemudian yang membuat peneliti menganggap penting untuk melakukan penelitian ini. peneliti ingin meneliti lebih dalam lagi tentang peran organisasi PKK dalam Pemberdayaan Perempuan di Kecamatan Telaga serta program-program PKK di Kecamatan Telaga. Bagaimana 10 program itu dijalankan dengan keterbatasan sumber daya manusia dan keterbatasan anggaran, sehingga Organisasi PKK masih menjadi salah satu organisasi yang keberadaanya dirasakan penting.

Penelitian mengenai peran dan fungsi PKK pada dasarnya telah banyak dilakukan. Salah satunya dilakukan oleh Ramandita Shalifah. Penelitian tersebut mengangkat judul Peran Pemberdayaan dan Kesejahteraan Keluarga (PKK) dalam mendukung program-program Pemerintah Kota Bontang. Penelitian tersebut menjelaskan mengenai peran PKK sebagai organisasi pembaharuan dan penggerak masyarakat belum berjalan optimal. Hal ini bisa dilihat manakala kondisi adanya sekretariat PKK dibeberapa desa, kelurahan dan kecamatan kurangnya kesadaran masyarakat dalam berorganisasi. Hal ini disebabkan oleh berbagai alasan misalnya tidak adanya waktu masyarakat 
untuk ikut melaksanakan kegiatan PKK, tidak adanya imbalan dana dalam setiap kegiatan PKK, dan tidak tersedianya sarana transportasi untuk menuju lokasi pelaksanaan kegiatan PKK.

Dalam mengatasi masalah tersebut maka pengurus PKK harus lebih meningkatkan kinerjanya dalam pada kegiatan PKK khususnya dalam mengajak dan membina keluarga agar masyarakat lebih semangat dalam mengikuti semua kegiatan organisasi ini dalam mensuport kegiatan program pemerintah Bontang. Pemerintahan diharapkan agar memperhatikan semua kegiatan PKK dengan memfasilitasi kegiatan-kegiatan dilakukan PKK.

Penelitian selanjutnya dilakukan oleh Desi Arisandi Tahun 2015 dengan judul Peran PKK di dalam Pemberdayaan Perempuan di Desa Muara Bengkal Ilir Kecamatan Muara Bengkal Kabupaten Kutai Timur. Pemerintah Desa Muara Bengkal Ilir juga sudah berupaya membantu Tim Penggerak PKK tersebut baik itu dalam hal dana/fasilitas (materil) maupun bantuan berupa pemikiran/motivasi (moril). Dari bantuan tersebut para penggerak PKK dapat menjalankan program yang sudah direncanakan. Kemudianpartisipasi para Istri pejabat Pemerintah untuk menjadi Tim Penggerak PKK jugasangat membantu proses berjalannya lembaga PKK tersebut dan antusiasnya parawarga/ibu-ibu rumah tangga untuk terlibat dalam lembaga PKK tersebut sangatmembantu proses terlaksananya program PKK.

Kedua penelitian yang telah dijelaskan di atas menunjukkan bahwa PKK pada kenyataanya memberian dampak signfikan bagi peningkatan kapasitas dan kesejahteraan keluarga khususnya kaum perempuan. PKK memberikan ruang aktualisasi bagi perempuan untuk lebih mengembangkan potensinya.

Adapun penelitian ini lebih lanjut membicarakan mengenai peran program PKK yang mengambil lokasi di Kecamatan Telaga. Secara lebih khusus akan membahas mengenai upaya yang dilakuakan oleh TP-PKK Kecamatan Telaga dalam mendukung program pemerintah terkait peningkatan kesejahteraan masyarakat dan peran partisipasi perempuan di dalamnya.

\section{METODE PENELITIAN}

Penelitian ini menggunakan jenis penelitian deskriptif dengan menggunakan metode kualitatif. Teknik yang digunakan dalam pengumpulan data Wawancara, yaitu melakukan tanya jawab dan diskusi secara langsung dengan pihak instansi, khususnya dengan bagian yang berhubungan dengan objek penelitian. dalam penelitian dilakukan wawancara langsung dari pengurus PKK Kecamatan telaga diantaranya Ketua TP PKK serta anggota pengurus PKK dan Masyarakat. Dokumentasi, yaitu dengan meneliti bahan-bahan tulisan instansi yang berhubungan dengan penelitian ini. mengumpulkan data serta lampiran foto saat penelitian dilapangan. Studi Kepustakaan, yaitu untuk memperoleh landasan teorimelalui literatur-literatur, artikel pada jurnal ilmiah,serta melakukan browsing internet mengenai segala hal yang terkait dengan penelitian di atas.

\section{HASIL DAN EMBAHASAN}

\section{PKK Sebagai Program Pemberdayaan} Masyarakat

Berdasarkan Permendagri Nomor 1 Tahun 2013 Pasal 1 bahwa: Gerakan Pemberdayaan dan Kesejahteraan Keluarga, selanjutnya disingkat Gerakan PKK merupakan gerakan Nasional dalam pembangunan masyarakat yang tumbuh Copyright (C 2019, Publik (Jurnal Ilmu Administrasi), ISSN: 2301-573X (Print), ISSN: 2581-2084 (Online) 
dari bawah yang pengelolaannya dari, oleh dan untuk masyarakat, demi menuju terwujudnya keluarga yang beriman danbertaqwa kepada Tuhan Yang Maha Esa, berakhlak mulia dan berbudi luhur, sehat sejahtera, maju dan mandiri, kesetaraan dan keadilan gender serta kesadaran hukum dan lingkungan.

Organisasi PKK yakni suatu wadah yang di dalamnya memberikan binaan terhadap perempuan dan masyarakat baik di perkotaan sampai dipedesaan yang menghasilkan suatu proses bagi keluarga sejahtera yang mandiri,yang bisa menghasilkan sinergi untuk keluarga sejahtera yang mandiri dengan meningkatkan mental spiritual perilaku hidup dengan menghayati dan mengamalkan Pancasila. dapat dikembangkan lebih luas lagi dengan berbagai upaya atau usaha dan kegiatan, seperti meningkatkan pendidikan dan ketrampilan yang diperlukan, ikut mengupayakan dalam kehidupan bangsa serta meningkatkan pendapatan keluarga, meningkatkan kualitas adan kuantitas pangan keluarga, meningkatkan derajat kesehatan, kelestarian lingkungan hidup serta membiasakan hidup berencana dalam semua aspek kehidupan dan perencanaan ekonomi keluarga dengan membiasakan menabung.

PKK memiliki sepuluh program pokok yang lebih dikenal sebagai Sepuluh Program Pokok PKK. lebih jelasnya program pokok tersebut ialah : 1). penghayatan dan pengamalan pancasila yakni dalam pelaksanaan meningkatkan kesadaran berkeluarga dalam kehidupan bermasyarakat berbangsa dan negara. dimana perlu dipahami hak dan kewajibannya sebagai warga negara dalam sosialisasi penyuluhan, pelatihan serta simulasi terpadu. 2) gotong royong yakni dalam pelaksanaan gotong royong perlu dibangun kerja sama yang baik sesama keluarga. 3) pangan yakni cara pengolahan akan kebutuhan makanan keluarga yang tentunya faktor terpenting untuk pertumbuhan kesehatan keluarga sejahtera. 4) sandang yakni cara pengelolaan terhadap kebutuhan keluarga sebagai kebutuhan hidup yang mempunyai pengaruh besar terhadap individu baik jasmani,rohani dan sosial. 5) perumahan dan tata laksana rumah tangga perumahan yakni sebagai kebutuhan hidup disamping sandang dan pangan. perumahan juga perlu terhadap kesejahteraan keluarga, sehingga diusahakan agar fungsi terhadap rumah sebagai tempat tinggal yang nyaman serta layak untuk ditinggali oleh keluarga. 6) pendidikan dan keterampilan yakni untuk meningkatkan pengetahuan dan juga kesadaran keluarga tentang tumbuh kembang anak dan juga balita secara optimal dan pentingnya Paud melalui BKB atau biasa di sebut bina keluarga balita.keluarga juga wajib tahu akan belajar pendidikan dasar 12 tahun. 7) kesehatan yakni pentingnya menjaga kesehatan individu ataupun kelompok serta lingkungannya. dengan mencakup pendidikan tentang kesehatan lingkungan,sumber air bersih kemudian pelestarian lingkungan hidup. 8) pengembangan kehidupan berkoperasi yakni memotivasi keluarga agar mau menjadi anggota koperasi demi meningkatkan pendapatan keluarga. 9) kelestarian lingkungan hidup yakni memberikan kebiasan membuang sampah pada tempatnya dan juga cuci tangan pakai sabut setelah buang air kecil/besar, sebelum makan,minum serta dalam mengelola makanan. 10) perencanaan sehat yakni meningkatkan penyuluhan tentang pentingnya pemahaman dan kesetaraan dalam program keluarga berencana menuju keluarga sejahtera dan berkualitas. 
Pemberdayaan Perempuan adalah upaya pemampuan perempuan untuk mremperoleh akses dan kontrol terhadap sumber daya, ekonomi, politik, sosial, budaya, agar perempuan dapat mengatur diri dan meningkatkan rasa percaya diri untuk mampu membangun kemanpuan dan konsep diri (Novian 2010:43). Pemberdayaan perempuan merupakan sebuah proses sekaligus tujuan. Sebagai proses, pemberdayaan adalah kegiatan memperkuat kekuasaan dan keberdayaan kelompok lemah dalam masyarakat. Pemberdayan perempuan upaya mengatasi hambatan guna mencapai pemerataan atau persamaan bagi laki-laki dan perempuan pada setiap tingkat proses pembanguan. Teknik analisis pemberdayaan perempuan khususnya dalam pembangunan mengembangkan teknik analisis genderyang dikenal dengan kerangka kemampuan perempuan .

$\begin{array}{lrr}\quad \text { United Nation of } & \text { Organization } \\ \text { merumuskan } & \text { beberapa } & \text { gagasan } \\ \text { yangberkaitan } & \text { denganpemberdayaan } \\ \text { perempuan yakni: } & \text { 1) Penanggulangan }\end{array}$
kemiskinan. 2) Keterlibatan semua orang secara adil dalam perekonomian. 3) Perbaikan kualitas hidup perempuan dan laki-laki berkenaan dengan aksesterhadap barang dan jasa yang esensial serta informasi yang di butuhkan untuk membuat pilihan. 4) Penciptaan basis-basis produktif untuk memenuhi kebutuhan penduduk danmemungkinkan keadaan perekonomian negara berubah. 5) Pembagian kerja secara Penciptaan pranata politik yang melindungi dan memungkinkan pelaksanaanhak asasi warga negara (termasuk hak-hak perempuan) dengan menyediakankondisikondisi bagi akses terhadap hak-hak tersebut yang memungkinkan konfliksosial di pecahkansecara damai. Penghargaan terhadap nilai kultural dan aspirasisebagai konflik sosial.

\section{Pelaksanaan Program PKK Kecamatan} Telaga

Berdasarkan hasil penelitian di Kecamatan Telaga bahwa TP PKK memiliki beberapaprogram-program PKK dari tahun 2016-2017 hingga pada pergantian Pengurus TP PKK Kecamatan Telaga periode 2018-2019 adalah sebagai berikut.

Tabel 1

Program-Program PKK Kecamatan Telaga Tahun 2018.

\begin{tabular}{cl}
\hline No. & \multicolumn{1}{c}{ Program PKK } \\
\hline 1. & $\begin{array}{l}\text { Yasin Fadillah di } \\
\text { laksanakan di setiap Desa }\end{array}$ \\
2. & $\begin{array}{l}\text { Penyuluhan Tentang } \\
\text { Perlindungan Anak }\end{array}$ \\
3. & $\begin{array}{l}\text { Pembinaan Kelompok } \\
\text { BKL,BKR }\end{array}$ \\
4. & Pelayanan Kesehatan \\
5. & $\begin{array}{l}\text { Pendataan Literasi PAUD } \\
\text { Se- Keamatan Telaga }\end{array}$ \\
6. & $\begin{array}{l}\text { Pemanfaatan Pekarangan } \\
\text { 7. }\end{array}$ \\
8. & PKK Momah Mobile \\
\hline Sumber $:$ PKK Kecamatan Telaga 2018
\end{tabular}

Adapun pelaksanaan Program PKK telah dilakukan secara optimal dalam menggerakkan masyarakat khususnya kaum perempuan sehingga pelaksanaan kegiatan program kerja PKK dapat berdaya guna.adapun Manfaat yang didapatkan dari program PKK Kecamatan Telaga tersebut tergambarkan dalam tugas dan fungsi Organisasi Tim Penggerak PKK dengan membentuk kelompok kerja dengan ketentuan yang khusus. Program-program PKK Kecamatan Telaga yang terdiri dari :

\section{Kelompok Kerja (Pokja) 1}

Membidangi kegiatan pelaksanaan program penghayatan dan pengamalan Pancasila dan program Gotong Royong, berdasarkan hasil pengamatan program 
PKK Kecamatan Telaga telah mengadakan pembinaan pemahaman tentang peraturan dan perundang-undangan, dalam program PKK Kecamatan telaga sampai pada kepengurusan saat ini dalam kegiatan Yasin fadilah tetap dilaksanakan setiap Seminggu Sekali, dimana menigkatkan pemahaman tentang surat yasin yang dilaksanakan di setiap Desa se Kecamatan Telagadan juga pelaksanaan program Gema Lingkungan Mandiri Sehat (Kambungu Beresi). Kegiatan PKK ini dilakukan untuk mengajak ibu-ibu melakukan sadar akan kebersihan lingkungan demi desa dan keluarga tercinta.

\section{Kelompok kerja (Pokja) II}

Membidangi kegiatan pelaksanaan Program Pendidikan dan Pengembangan kehidupan berkoperasi, berdasarkan hasil pengamatan program PKK Kecamatan Telaga telah melakukan kegiatan Pendataan Literasi PAUD Se- Kecamatan Telaga untuk mengetahui jumlah lembaga PAUD yang ada di Kecamatan Telaga dan Pelatihan Keterampilan dalam memanfaatkan bahan dasar limbah serta pelatihan untuk ibu-ibu dalam membuat kerajinan Tangan (karawo-kain khas Gorontalo). ada juga kegiatan pelatihan oleh PKK Kecamatan Telaga tentunya bisa dimanfaatkan oleh ibu-ibu rumah tangga. hal ini berkaitan dengan Program PKK Kecamatan Telaga dimana akan mendapatkan dampak banyak dari kegiatan pelatihan hasil karya kerajinan kemudian hasil kerajinan tersebut tentunya bisa digunakan untuk meningkatkan pendapatan di keluarga.

\section{Kelompok kerja (Pokja) III}

Membidangi kegiatan pelaksanaan Program Pangan, sandang, perumahan dan tata laksana rumah tangga, dimana berdasarkan hasil pengamatan program PKK Kecamatan Telaga yang telah melakukan

kegiatan

pemanfaatan pekarangan rumah yang di tanami tanaman Toga dimana untuk meningkatkan pemahaman masyarakat terhadap pentingnya tentang pengelolaan lingkungan bersih dan sehat, serta lomba cipta menu berbasis pangan lokal dan tradisional untuk meningkatkan reaktifitas ibu-ibu PKK dalam mengelola Pangan lokal dan tradisional. Kegiatan ini sejalan dengan misi PKK Kecamatan Telaga yaitu meningkatkan kualitas dan kuantitas pangan keluarga.

\section{Kelompok kerja (Pokja) IV}

Membidangi kegiatan pelaksanaan Program Kesehatan, kelestarian lingkungan hidup dan perencanaan sehat, berdasarkan hasil pengamatan program PKK Kecamatan Telaga telah melakukan kegiatan pelayanan kesehatan seperti memantapkan keluarga sadar Gizi, penyuluhan pentingnya imunisasi bagi ibu, bayi dan calon ibu yang tujuannya adalah meningkatkan imunisasi sebagai kebutuhan dasar bayi dan TP PKK kecamatan telaga berperan aktif.

Berdasarkan hasil wawancara dengan ketua TP PKK Kecamatan Telaga menyatakan bahwa semua kegiatan ini berada di bawah naungan di setiap Pokja PKK. dimana setiap ketua kelompok kerja ini melaksanakan tugas dan fungsinya masing-masing. dalam program ini juga, PKK selalu memberikan pelatihan keterampilan untuk melatih kemampuan ibu-ibu biar mereka kreatif seperti mendaur ulang bahan-bahan daur ulang dan juga melatih ibu-ibu dalam membuat kerajinan tangan karawodan PKK juga dapat menggali potensi yang terdapat di masyarakat Desa se Kecamatan Telaga (Wawancara tanggal 10 April 2019).

Pengurus PKK periode 2016-2017 dalam melaksanakan tugas dan fungsinya kurang optimal dalam memberikan 
Pembinaan seperti kegiatan pendidikan dan pelatihan kepada ibu-ibu PKK. Setelah terjadi pergantian Kepengurusan PKK Periode 2017-2019 sampai sekarangmulai terlihat kegiatan PKK dalam bagian pemberian Pembinaan kepada Ibu-ibu dan anggota PKK itu sendiri di Kecamatan Telaga dilakukan walaupun masih terbatas terutama pada kegiatan pelatihan dalam memberdayakan Kaum Perempuan. Dalam pelaksanaan program-program PKK yang tergabung dalam kelompok kerja dari Pokja I sampai Pokja IV dituntut untuk bersifat kreatif dan inovatif. Misalnya padapemeberian pelatihan, kursus, dan kegiatan-kegiatan lainnya dalam memberdayakan kaum Perempuan yang ada di Desa yang tentunya semuan tidak terlepas dari tujuan PKK yakni dapat meningkatkan kesejahteraan keluarga dan pendapatan keluarga.

Penjelasan sebelumnya telah sejalan dengan pendapat salah seorang pengurus PKK Kecamatan Telaga Biru UD mengenai usaha yang dilakukan dalam Pemberdayaan Perempuan itu sendiri, mengatakan bahwa kegiatan PKK semacam melakukan kegiatan-kegiatan yang membangun yaitu dengan mengadakan kegiatan acara yasiin fadilah secara rutin yang selalu dilaksanakan di setiap desa dengan cara bergilir ini semua tentunya bertujuan membangun atau memotivasi jiwa kerohanian kita sendiri,dan ada juga pemberdayaan kelompok perempuan di setiap desa seperti hal kegiatan peningkatan keterampilan masyarakat dalam kerajinan karawo yang tujuannya untuk meningkatkan produktivitas kaum perempuan demi menambah perekonomian keluarga serta ada juga kegiatan PKK lainnya dalam mengadakan kegiatan masak-memasak seperti mengadakan lomba cipta menu non beras yang setiap desa mewakili utusannya ditingkat Kecamatan (Wawancara tanggal 10 April 2019).

Selain memberikan pelatihan keterampilan PKK juga melaksanakan kegiatan lomba cipta menu, Ketua TP. PKK Kecamatan Telaga selalu mengajak ibu-ibu PKK ke dalam kegiatan PKK lainnya, ada seperti pada Penyuluhan Tentang Kesehatan, serta melaksanakan kegiatan Lomba TOGA artinya Ibu-ibu PKK bisa memanfaatkan pekarangan rumahnya untuk ditanami Tanaman rempah-rempah (Dapur Hidup) yang hasilnya dirasakan oleh masyarakat sendiri. dan juga mengajak kedalam kegiatankegiatan yang lain dan dengan adanya kegiatan tersebut masyarakat atau ibu-ibu serta anggota PKK Kecamatan Telaga bisa menjadi lebih baik lagi (Wawancara tanggal 11 April 2019).

Sebagaimana diuraikan sebelumnya bahwa Organisasi PKK memiliki peran penting dalam terwujudnya keluarga yang maju,mandiri serta sejahtera, tentunya sasaran dari program PKK yang di paparkan meliputi : BKL (binaan keluarga lansia), BKR (binaan keluarga remaja, masyarakat dan perempuan).

Berdasarkan penelitian penulis bahwa dalam Program-program PKK khususnya Pemberdayaan Perempuan di Kecamatan Telaga dari Ketua TP PKK bisa dikatakan dalam kategori baik. kegiatan dilakukan masing-masing per kelompok kerja yang sudah dibagi tupoksinya dan senantiasa selalu mengajak ibu-ibu PKK kecamatan Telaga untuk ikut serta kedalam setiap kegiatan per pokja itu sendiri. Serta Organisasi PKK sendiri melakukan usaha didalam Pembinaan semaksimal mungkin dan didalam hal memberdayakan Perempuan yang ada di Kecamatan Telaga.

\section{Pemberdayaan Ekonomi}

Secara etimologi, kata 'berdaya' mengandung makna "berkemampuan, Copyright @ 2019, Publik (Jurnal Ilmu Administrasi), ISSN: 2301-573X (Print), ISSN: 2581-2084 (Online) 
bertenaga, berkekuatan”, kata 'daya' sendiri bermakna "kesanggupan untuk berbuat, kesanggupan untuk melakukan kegiatan". Pemberdayaan (yangmerupakan proses) menjadi manusia sebagai pribadi yang berdaya denganbanyaknya pilihanpilihan yang bisa diambil tanpa ada tekanan atau paksaan, sebagaimana yang di sampaikan oleh Edi Suharto (2006) bahwa berdaya itu adalah ketika tersedianya pilihan-pilihan untuk memilih atau memiliki sesuatu.

Berdasarkan wawancara dari salah satu anggota Pengurus PKK Kecamatan Telaga mengatakan bahwa sebagian masyarakat dan ibu-ibu mendapatkan pendapatan demi keluarga untuk menambah hasil dari mengembangkan usaha kerajinan Tangan Karawo. dengan membuat kerajinan tangan karawo milik orang lain tergantung atau sesuai dengan permintaan. dari hasil Pendapatan usaha inilah tentunya sangat membantu kebutuhan masyarakat dari mulai membeli segala perlengkapan peralatan anak-anak demi keperluan sekolah juga kebutuhan rumah secara mendasar (Wawancara tanggal 11 April 2019). Meningkatnya usaha membuat Karawo dapat dilihat dari permintaan kebutuhan orang dalam permintaan pembuatan pakaianmulai dari baju orang dewasa sampai pakaian anakanak mereka yang bahan dasarnya adalah kain karawo yang telah di modivikasi dengan sebaik mungkin.

PKK mempunyai strategi dalam pemberdayaan perempuan dengan memanfaatkan sumber daya, sehingga perempuan tidak hanya sebagai ibu rumah tangga saja yang hanya berdiam diri saja, tetapi menjadikan perempuan di desa-desa se Kecamatan Telaga lebih aktif dalam dunia kerja, sehingga membantu suami dalam meningkatkan pendapatan keluarga. melalui pendekatan antara pengurus PKK dengan ibu-ibu.

\section{Peran Organisasi PKK Kecamatan Telaga dalam Memberdayakan Perempuan}

Peran sebagai pembinaan pemberdayaan perempuan adalah salah satu bentuk kegiatan yang dilaksanakan oleh PKK Kecamatan Telaga. PKK juga menghimpun, menggerakkan dan kemudian membina potensi masyarakat terlebih dalam pengembangan pemberdayaan perempuan dan juga menyusun rencana dari pelaksanaan kegiatan program kerja PKK yang sesuai dengan kebutuhan, keadaan masyarakat dalam pembinaan itu sendiri.

Demi melaksanakanya kegiatan organisasi PKK tentunya menggunakan atau berpacu dan lebih prioritas keprogram yang disusun oleh pengurus setiap tahunnya, dengan mengutamakan kegiatan program prioritas yang dibutuhkan oleh masyarakat khususnya perempuan dan bisa disesuaikan juga dengan kemampuan masing-masing wilayah. dengan cara penyuluhan-penyuluhan, lebih keorientasi dan pelatihan-pelatihan serta dalam upaya meningkatkan pengetahuan, keterampilan dan pendapatan keluarga. PKK Kecamatan Telaga ini telah melaksanakan program lebih memfokuskan pada memberdayakan perempuan, berdasarkan pengamatan teridentifikas peran PKK Kecamatan Telaga melalui peran sebagai berikut:

Peran Kegiatan Program Kesehatan yang dilakukan oleh PKK Kecamatan Telaga merupakan suatu kegiatan yang dilakukan 1 bulan sekali dalam membina keluarga sehat dengan memberi penyuluhan dan mengembangkan pengetahuan, upaya perbaikan gizi keluarga melalui sosialisasi pemberian makanan tambahan bagi anak, usaha 
kesehatan sekolah, kebersihan pribadi maupun lingkungan.

Peran Kegiatan Pendidikan dan Keterampilan juga adalah kegiatan PKK Kecamatan Telaga yang dilaksanakan. kegiatan pelatihan keterampilan kerajinan Karawo dan juga dari bahan dasar limbah bagi ketua dan anggota dasa wisma, terutama dalam pelatihan kader yang selalu bekerja sama dengan KUPTB Kecamatan Telaga pada setiap kegiatan PKK Mobile.

Peran PKK Kecamatan Telaga dalam memonitoring kegiatan kelompok UP2KPKK dalam meningkatkan ekonomi keluarga yang dapat di paparkan sebagai bentuk implementasi atau hasil dari program pemberdayaan perempuan di tingkat kabupaten,kecamatan atau desa. serta mengadakan pemanfaatan pekarangan Rumah untuk di tanami tanaman Rempahrempah (dapur hidup) dan di tanami obatobatan (toga) dalam rangka pemberdayaan perempuan.

Organisasi PKK merupakan wadah sebagai Penggerak utama dan keluarga menjadi tujuan dari gerakan PKK. dimana sebagai gerakan Perempuan yang di jalankan atau dioperasikan pada tingkat Pemerintah paling bawah maka PKK ini tentunya bertujuan untuk membantu kelancaran birokrasi Pemerintah Kecamatan Telaga. Peran PKK dan Kader menentukan keberhasilannya program PKK.

Kaum Perempuan sangat aktif dalam mengadakan penyuluhan yang berkaitan dengan programnya sampai ke tingkat desa-desa. dengan kondisi seperti itu, perempuan tidak hanya cuman sebagai pendamping suami akan tetapi telah aktif dan dilatih untuk selalu mendukung berhasilnya program Pemerintah di Kecamatan Telaga.

Ibu-ibu sebagian sudah memiliki jiwa perilaku sadar dan peduli sehingga merasa membutuhkan peningkatan diri Copyright @ 2019 , Publik (Jurnal Ilmu Administrasi), ISSN: 2301-573X (Print), ISSN: 2581-2084 (Online) dengan turut serta dalam setiap kegiatan yang di laksanakan oleh PKK Kecamatan Telaga khususnya yang berkaitan langsung dengan pemberdayaan perempuandengan membantu pendapatan keluarga.

Strategi inilah yang terus dilakukan PKK dalam pemberdayaan perempuan pada ibu-ibu di Kecamatan Telaga yang sejalan dengan teori Peran Oleh Soekanto, dimana Peran adalah aspek dinamis dari kedudukan (status). jika seseorang melaksanakan hak dan kewajibannya sesuai dengan kedudukannya, maka dia menjalankan suatu peran. dimana teori ini meliputi peran dari pada PKK Kecamatan Telaga dalam upaya untuk meningkatkan pemberdayaan perempuan dalam kesejahteraan keluarga.

Menurut Soekanto (2002 : 243) peranan mencakup tiga hal yaitu: 1) Peranan meliputi norma-norma yang dihubungkan dengan posisi atau tempat seseorang dalam masyarakat. Peranan dalam arti ini merupakan rangkaian peraturan-peraturan yang membimbing seseorang dalam kehidupan kemasyarakatan. 2) Peranan adalah suatu konsep tentang apa yang dapat dilakukan oleh individu dalam masyarakat sebagai organisasi. 3) Peranan juga dapat dikatakan sebagai perilaku individu yang penting bagi struktur sosial masyarakat.

Upaya Ketua PKK Kecamatan Telaga didalam mengajak ikut serta dalam kegiatan selama ini untuk menambah wawasan kepada ibu-ibu rumah tangga di Desa Se-Kecamatan Telaga dalam pemberdayaan perempuan dengan yang tidak memiliki pekerjaan sehingga menjadi memiliki pekerjaan sebagai penambah penghasilan rumah tangga mereka itu sendiri.Adanya hubungan yang kondusif antara ibu-ibu PKK dengan Ketua PKK Kecamatan Telaga dan anggotanya didalam menjaga jalinan komunikasi dan 
silaturahmi yang baik sebagai sesama masyarakat Desa se Kecamatan Telaga.

Sikap keterbukaan Ketua TP.PKK yang selalu menerimakritik dan saran Ibuibu dan masyarakat Kecamatan Telaga dan anggota nya sangat terbuka apalagi mengenai kiat dan usaha yang dilakukan dalam pemberian pengetahuan dan wawasan yang pernah diberikan selama ini.Upaya Ketua PKK Kecamatan Telaga dan anggotanya didalam Pembinaan (Pendidikan dan Pelatihan) di dalam memberdayakan Masyarakat dan Perempuan serta Memotivasi dan memfasilitasi mereka agar bisa menambah pengalaman serta wawasan dan pengetahuan yang telah ada dan diberikan menjadi lebih baik lagi kedepannya.

Berdasarkan Penelitian bahwa Peranan PKK dan pengaruhnya terhadap perempuan dalam memberdayakan perempuan. Dilihat dari program kerja PKK Kecamatan Telaga yang mempunyai prioritas program berupa Usaha Peningkatan Pendapatan Keluarga (UP2K) yang dijadikan sebagai basis implementasi dari pemberdayaan Perempuan. Terlebih dalam program ini peran perempuan yang selama ini mayoritasnya termarjinalisasi dalam sektor kehidupan sosial dan ekonomi. perempuan dalam sektor sosial dan ekonomi, pada akhirnya akan mampu menciptakandinamika dalam rangka pemberdayaan.

Berdasarkan hasil wawancara oleh pengurus PKK Kecamatan telaga mengatakan bahwa PKK Kecamatan Telaga memiliki Kualitas yang baik dalam hal Pemberdayaan Perempuan. hal tersebut di tunjukkan salah satunya adalah dengan ditunjukkan PKK Kecamatan Telaga untuk mengikuti pelatihan kader yang bekerja sama dengan KUPTB Kecamatan Telaga pada kegiatan PKK mobile. kemudian program pelatihan pemberdayaan perempuan mandiri PKK dalam wujud pemanfaatanpekarangan rumah sebagai media tanam untuk tumbuhan TOGA dan juga Dapur hidup. dimana hasil tersebut mampu menambah pendapatan keluarga, serta menumbuhkan ekonomi kreatif ibuibu di Kecamatan Telaga lanjut juga dalam Bidang Kesehatan pun PKK menyelenggarakan kegiatan IVA TEST untuk mendeteksi dini kejadian kanker mulut rahim bagi kaum perempuan.adanya pelayanan keluarga berencana (KB) dan posyandu.

Berdasarkan penelitian penulis bahwa program PKK Kecamatan Telaga ini memiliki monitoring yang baik. sebagaimana yang disampaikan oleh pengurus PKK Kecamatan Telaga. Data mengenai kegiatan-kegiatan PKK diperoleh berdasarkan hasil wawancara dengan Ketua TP-PKK Kecamatan Telaga beserta Anggota Pengurus PKK Kecamatan Telaga pada tanggal 10 April 2019.

Dari hasil penelitian ini diperoleh bahwa pada kenyataannya program PKK memang diprioritaskan dalam pengembangan masyarakat khususnya perempuan. Hasil yang diperoleh dari penelitian ini juga tidak jauh berbeda dengan kesimpulan pada penelitian sebelumnya. Dimana implementasi program PKK memang memberikan dampak yang signifikan dalam pembangunan daerah secara keseluruhan.

\section{PENUTUP}

\section{Kesimpulan}

Berdasarkan uraian-uraian yang telah dipaparkan sebelumnya maka penulis menarik kesimpulan bahwa pelaksanaan program PKK Kecamatan Telaga telah berhasil memberdayakan masyarakat. Keberhasilan yang telah dirasakan oleh anggota PKK, keluarga dan masyarakat ini 
tentunya dengan adanya dukungan dan keterlibatan aktif dari instansi terkait di tingkat kecamatan. Serta atas adanya pembinaan langsung oleh pengurus TP PKK Kabupaten Gorontalo kepada TP PKK Kecamatan hingga ke Desa.

\section{Saran}

Tidak dapat dipungkiri bahwa program PKK belum sepenuhnya dilaksanakan. Namun sedikit banyak keberhasilannya atas kegiatan yang dilakukan oleh PKK Kecamatan Telaga sudah dapat dirasakan dan menyentuh kepentingan masyarakat sampai dipelosok lingkungan melalui kegiatan-kegiatan PKK. Untuk itu masih diperlukan maksimalisasi dalam implemetasi program PKK, khusunya dalam bidang pengawasan. Hal ini agar program-program yang dijalankan mampu mencapai target seperti yang diharapkan.

\section{DAFTAR PUSTAKA}

Anderson, J.E. (1979). Public Policy Making $\quad\left(2^{\text {nd }}\right.$ ed). New York, NY:Holt, Rinchart \& Winston.

Anwar, Oos M. (2013). Pemberdayaan Masyarakat di Era Global, Alfabeta : Bandung

Iqbal, M. M. (2019). Menakar Partisipasi Politik Perempuan di Kabupaten Malang (Studi di KPUD Kabupaten Malang). Gorontalo Journal of Government and Political Studies, 2(1), 032-041.

Miles, Mathew. B dan A. Micheal Huberman. (2007). Analisis Data Kualitatif. University Indonesia. Jakarta

Pontoh, L., Goni, J. H., \& Ruindungan, R. (2018). Peran Perempuan Pegawai Negeri Sipil dalam Pemerintah
Daerah Kabupaten Bolaang

Mongondow Utara. Publik (Jurnal Ilmu Administrasi), 2(2), 15-18.

Soekanto, Soerjono. (1992). Sosiologi: Suatu Pengantar. PT. Raja Grafindo, Jakarta

Sugiyono. (2013). Metode Penelitian Kualitatif. Bandung : Alfabeta.

Wolfman, BR. (1989). Peran Kaum Perempuan : "Bagaimana Menjadi Cakap dan Seimbang dalam Aneka Peran." Cetakan Ketiga. Yogyakarta: Kanisius

Winardi, J. (2003). Teori Organisasi dan Pengorganisasian Ed.1.Cet 2. Jakarta : PT Raja Grafindo Persada.

Wadu, L. B., Ladamay, I., \& Dadi, M. Y. (2018). Faktor Pendukung dan Penghambat Pembinaan Kesejahteraan Keluarga (PKK) Dalam Meningkatkan Keterampilan Warga Negara Melalui Program Pokok PKK. Jurnal Inspirasi Pendidikan, 8(1), 62-71. 